\title{
Elintarvikkeiden ympäristövaikutusten vertailukelpoinen laskenta
}

Juha-Matti katajajuuri, Hannele Pulkkinen, Hanna Hartikainen, Kristoffer Krogerus, Frans Silvenius, Merja Saarinen, Kirsi Usva \& Heli Yrjänäinen

MTT Biotekniikka- ja elintarviketutkimus, Latokartanonkaari 9, 00790 Helsinki

\section{Tiivistelmä}

Elintarvikealan yritykset laskevat aktiivisesti tuotteidensa hiilijalanjälkiä ja jotkut yrityksistä ovat myös merkinneet osan markkinoilla olevista tuotteistaan itse laatimillaan hiilijalanjälkimerkinnöillä. Tuotteiden elinkaariarvioinnin periaatteet ovat olleet standardoituja vuodesta 1996 lähtien (ISO 14040 ja ISO 14044). Standardit päivitettiin vuonna 2002, ja sen jälkeen erilaisten laskentaohjeistusten kehitys on ollut erityisen intensiivistä. Näillä laskentaohjeistoilla on pyritty yhtenäistämään elinkaariarvioinnin käytäntöjä standardeja yksityiskohtaisemmin, Viime vuosina hiilijalanjäljet eli elinkaariset kasvihuonekaasupäästöt eli ilmastovaikutukset ovat nousseet elinkaarilaskennan keskiöön.

BSI:n PAS 2050-ohje tuotteiden kasvihuonekaasupäästöjen arvioimiseksi on nyt ollut saatavilla pari vuotta. Ohje on jo kertaalleen päivitettykin (PAS 2050:2011). EC julkaisi alkuvuonna 2010 liki tuhatsivuisen seitsemään ohjekirjaan jakautuvan elinkaarilaskentaohjeistuksensa (ILCD). WRI ja WBCSD puolestaan julkaisivat loppuvuonna 2011yhteisen tuotteiden GHG Protocol -ohjeistuksensa. Kansainvälinen standardisoimisliitto (ISO, International Organization for Standardization) julkaisee oman tuotteiden hiilijalanjälkistandardinsa 2013 (ISO 14067-2). Kaikki edellä mainitut pohjautuvat enemmän tai vähemmän ISO 14040-sarjaan. Myös European Food Sustainable Consumption and Production Round Table on lähtenyt kehittämään jalanjälkien standardointia, mutta ainakin toistaiseksi työ on edennyt hitaasti.

Kehitystyöstä huolimatta yleisesti hyväksyttyä ja laajasti käytettyä standardia tai muuta ohjetta ei ole vielä saatavilla, eikä läpimurto sellaisen saamiseksi näytä olevan tapahtumassakaan. Elinkaariarvioinnissa on useita päätöksenteko- ja valintatilanteita, joihin ISO- standardi ja suurin osa muistakaan ohjeista ei pysty tarjoamaan yksiselitteisiä ratkaisuja. Julkaistut kansainväliset ohjeistukset ovat hyvin yleisluontoisia, koska niitä on tarkoitus pystyä soveltamaan kaikkiin tuotteisiin eri tuotannonaloilla. Näin ollen niitä ei voi käyttää ainoana ohjeena tuotteiden ympäristövaikutusten laskemiseksi, jos halutaan että eri tuotteita koskevat lopputulokset ovat keskenään vertailukelpoisia.

Näistä lähtökohdista ja yritysten tarpeista vuoden 2009 lopulla käynnistynyt Tekes-rahoitteinen Foodprint Tools-hanke on loppusuoralla. Hankkeessa on työstetty kansallista laskentasuositusohjetta elintarvikkeiden jalanjälkien laskentaan. Työn tavoitteena on ollut yhtenäistää elintarvikkeiden ympäristövaikutusten, erityisesti hiilijalanjälkien laskentaa. Ohje perustuu ISO:n standardeihin, mutta keskittyy käytännön ratkaisujen yhdenmukaistamiseen, kuten mitkä vaiheet tarkasteluun sisällytetään ja minkälaista tietoa tuotantoketjun eri vaiheista pitäisi käyttää. Tämän julkisen kehityshankkeen rinnalla on meneillään kolme yrityshanketta, joissa testataan erilaisia tapoja kerätä tietoa koko ketjusta sekä varmistetaan ohjeiden toimivuutta ja tarkoituksenmukaisuutta. Hankkeiden lopullisena tavoitteena on, että elintarvikeyritykset pystyisivät tuottamaan luotettavaa, vertailukelpoista ja helposti päivitettävää hiilijalanjälkitietoa tuotteistaan.

Hankkeessa on järjestetty työpajoja, joihin on kutsuttu osallistujia elintarvikeketjuista ja niiden sidosryhmistä. Paikalla on ollut mm. kaupan, teollisuuden ja hallinnon edustajia sekä erityisen paljon alkutuotannon edustajia. Työpajoissa on keskitytty tiedontuotannon haasteisiin. Keskusteluun ovat nousseet esimerkiksi tiedon tarve ja selkeys, epävarmuus ja -selvyys tietojen luovuttamisesta ja käyttämisestä, kustannukset ja lisääntyvä työmäärä. Samalla kuitenkin on löydetty myös ratkaisuja, hyviä tavoiteltavia periaatteita ja motivaatiotekijöitä, kuten tiedon lisääminen, oikeudenmukaisuus koko ketjussa, benchmarking, jatkuva parantaminen sekä ketjun toimijoiden avoin keskustelu, viestintä ja ketjun toimijoiden yhteisten tavoitteiden asettaminen. Keväällä 2012 järjestetään hankkeen viimeinen laaja työpaja, jonka jälkeen laskentasuositukseen tehdään viimeiset mahdolliset muutokset ja täsmennykset ennen sen julkaisemista.

Lisätietoa: Foodprint-hankkeen kotisivut www.mtt.fi/foodprint 


\section{Johdanto}

Elintarvikkeiden hiilijalanjäljet, eli elintarvikkeiden elinkaaren aikana syntyvät ilmastovaikutukset, ovat nousseet viime aikoina laajasti yhteiskunnallisen ja kansalaiskeskustelun kohteeksi. Mitattavuutensa, tunnettavuutensa ja tärkeytensä vuoksi hiilijalanjäljet ovat elintarvikealan yritysten ympäristöjohtamisen ja viestinnän keskiössä. Suomessa yksityisen kulutuksen ilmastotaakasta noin neljännes aiheutuu syömisestä. Myös muut ympäristövaikutukset ovat tärkeitä. Elintarvikealan ympäristövastuun tulisi kattaa myös muut päästöt ilmaan, vesistöihin ja maaperään, sekä edelleen päästöjen haitalliset vaikutukset ympäristöön ottaa huomioon. Elintarvikkeilla on erityisen merkittävä rooli vesistöjen rehevöitymisessä. Elintarvikkeiden tuottaminen vaikuttaa ympäristöön myös muuten kuin päästöjen kautta. Maataloustuotanto vaikuttaa voimakkaasti esimerkiksi luonnon monimuotoisuuteen eli biodiversiteettiin.

Ympäristöasioiden hallinnasta on tullut merkittävä kilpailuetutekijä elintarvikealalla, niin kansainvälisesti kuin Suomessakin. Esimerkiksi merkittävän kansainvälisen elintarvikkeiden ja hygieniatuotteiden valmistajan Unileverin visiona on tuplata yrityskokonsa kuitenkin niin, että samalla sen jalanjäljet pienenevät. 2020 mennessä Unilever tavoittelee tuotteidensa jalanjälkien puolittamista.

\section{Elintarvikkeiden ympäristövaikutuksille yhtenäiset laskentasuositukset Suomessa}

Maailmalla on noussut tarve yhtenäisille tuotteiden ympäristövaikutusten elinkaarilaskennan standardeille. Yhteisiä sääntöjä tarvitaan vertailukelpoisten hiilijalanjälki- ja muiden jalanjälkitulosten tuottamiseksi ja viestimiseksi. Suomessa elintarvikeala on proaktiivisesti etenemässä ympäristövaikutusten määrittämisen ohjeistuksen ja laskentamallien harmonisoinnissa.

MTT on työstämässä ohjetta elintarvikkeiden hiilijalanjälkien arvioimiseksi yhteistyössä kotimaisten elintarvikealan yritysten ja kaupan kanssa. Ohje palvelee alan yrityksiä yksityiskohtaisessa tuotteiden ympäristövaikutusten, erityisesti hiilijalanjälkien arvioinnissa ja toimitusketjujen kehittämisessä ympäristöä vähemmän kuormittaviksi. Samalla se parantaa tuotteiden hiilijalanjälkien vertailtavuutta. Ohje tehdään pääosin Tekesin rahoittamassa, vuonna 2009 alkaneessa julkisessa Foodprint Tools -hankkeessa vuorovaikutuksessa yritysten omien, niin ikään Tekesin rahoittamien, kehityshankkeiden kanssa. Laskentasuositus valmistuu vuoden 2012 aikana. Se tulee ohjeistamaan yksityiskohtaisesti esimerkiksi tuotejärjestelmän rajauksia, allokointeja ja tiedon laatuvaatimuksia. Samalla hankkeessa tuotetaan työkaluja hiilijalanjäljen laskennan harmonisointiin julkaisemalla harmonisoituja maatalouden päästöjen laskentamalleja.

Kansallinen ohje perustuu kansainvälisille elinkaaristandardeille (ISO 14040-sarja), mutta keskittyy käytännön ratkaisujen yhdenmukaistamiseen, kun taas kansainväliset standardit tarjoavat elinkaariarvioinnin periaatteet ja käytännönratkaisujen yleisen kehikon. Julkisen metodologian kehityshankkeen rinnalla on meneillään kolme ketjuhanketta, joissa yritykset selvittävät omien tuotteidensa ympäristövaikutuksia ja kehittävät ketjunsa toimintaa vaikutusten vähentämiseksi. Yrityshankkeissa testataan erilaisia tapoja kerätä tietoa koko ketjusta sekä varmistetaan ohjeiden toimivuus ja tarkoituksenmukaisuus. Tavoitteena on, että jatkossa suomalaiset elintarvikeyritykset pystyisivät tuottamaan luotettavaa, vertailukelpoista ja helposti päivitettävää ympäristövaikutustietoa tuotteistaan. Lopullisena päämääränä on pienentää kotimaisen elintarvikeketjun ympäristövaikutuksia.

\section{Kansainvälinen harmonisointi riittämätöntä}

Tällä hetkellä on olemassa muutamia kansainvälisiä yleisen tason tuotteiden hiilijalanjäljen laskentaohjeistuksia (BSI:n PAS2050 ja WRI/WBCSD:n GHG-protokolla) ja lähivuosina niitä tullaan julkaisemaan lisää. Euroopan komissio julkaisi monisatasivuisen, ISO-14040-sarjaan pohjautuvan seitsemään ohjekirjaan jakautuvan elinkaarilaskentaohjeistuksensa (ILCD) 2010. Kansainvälinen standardisoimisliitto julkaissee tuotteiden hiilijalanjälkistandardinsa 2013 (ISO 14067-2). Jo olemassa olevat laskentaohjeet ja standardit ovat hyvin yleisluontoisia eivätkä ne tarjoa käytännönläheisiä ja selkeitä ohjeita, koska ne on tehty sovellettaviksi kaikilla tuotannonaloilla. Jossain vaiheessa eri standardien laadinnassa oli kovaakin keskinäistä vääntöä, mutta nyt niissä on sentään pyritty entistä enemmän keskinäiseen ristiriidattomuuteen. Yleisempien ohjeistuksien lisäksi on aloitettu tarkempien sektori- ja tuoteryhmäkohtaisten ohjeistuksien laatiminen, mutta ne ovat vielä kehittämisen alkuvaiheessa. 
Kansainvälistä yleisesti hyväksyttyä ja laajasti käytettyä, käytännöllistä ohjeistusta ruokatuotteille ei ole vielä saatavilla tai odotettavissa lähiaikoina.

Julkaistut kansainväliset ohjeet ovat käytännön laskennan kannalta turhan yleisiä esimerkiksi yrityksille. Ne eivät voi käyttää standardeja ainoana ohjeenaan tuotteiden hiilijalanjälkien laskemiseksi. Elinkaariarvioinnissa on useita päätöksenteko- ja valintatilanteita, joihin yleinen standardi ei pysty tarjoamaan yksiselitteisiä ratkaisuja. Esimerkiksi päästöjen allokointiin tarjotaan paljon vapauksia. Tiedonlaatuvaatimukset ovat myös hyvin tulkinnanvaraisia ja niitä tulkitaankin maailmalla hyvin vaihtelevasti.

Joissain asioissa kansainvälisesti ollaan toki yhtä mieltä. Hiilijalanjälkien tulee olla johdettavissa kasvihuonekaasujen lämmityspotentiaaliin (GWP) ja sitä kautta mahdollisimman todellisiin ilmastovaikutuksiin. Mikään laskentaohjeistuksista ei myöskään hyväksy kompensaatioita (off-setting) varsinaisessa tuotteen hiilijalanjäljen laskennassa, eli tarkasteltavan ketjun ulkopuolella tehtyä kasvihuonekaasujen sitomista tai päästöjen ehkäisemistä ei saa vähentää tuotteen hiilijalanjäljestä, vaan ne pitää ilmoittaa erikseen. Tuotteen hiilijalanjälki ei siis ole nolla, vaikka sen tuotannosta syntyviä kasvihuonepäästöjä vastaava päästömäärä poistettaisiinkin ilmasta jollain kompensaatiotoimella tuotteen valmistajan toimesta. Ohjeistuksissa hiilijalanjälki-termin on haluttu viittaavan yksinomaan tuotantoprosessin kasvihuonekaasuintensiteettiin. Periaatteen taustalla on pyrkimys yksiselitteisyyteen ja toisaalta myös huoli kuluttajien hämäämisestä. Käytännön ympäristömarkkinoinnissa tätä periaatetta on kierretty käyttämällä termiä "hiilineutraali tuote" silloin, kun yritys kompensoi tuotteen ilmastovaikutuksen poistamalla ilmakehästä jollain toimenpiteellä tuotteen tuotannosta aiheutuneen määrän kasvihuonekaasuja.

Kaikkien kansainvälisten ohjeiden lähtökohtana on elinkaarilaskenta, mutta kuinka kattavasti elinkaarta ja sen osa-alueita tulee sisällyttää laskentaa, onkin jo enemmän tulkinnanvaraista. Tuotteiden hiilijalanjäljen laskenta eroaa elinkaariarvioinnista ainoastaan siis siinä, että siinä keskitytään vain ja ainoastaan elinkaaren aikaisiin kasvihuonekaasupäästöihin, eli muita ympäristövaikutuksia ei huomioida.

\section{Elintarvikkeiden hiilijalanjäljet eivät ole vertailukelpoisia - toistaiseksi}

Yleisen luonteensa takia kaikki standardit viittaavat tavalla tai toisella tuoteryhmäkohtaisiin tarkempiin laskentaohjeisiin (PCR, Product Category Rules). Niitä on tehty eri maissa, mutta nekin ovat jääneet usein valitettavan yleisiksi. Lisäksi niiden haasteena on keskinäinen harmonisointi. Mikään taho ei tarkasta kaikkien PCR:ien laatua, ja niitä tehdään hieman eri tavoin ja päällekkäisille tuoteryhmille eri maissa.

Standardien ja tuoteryhmäkohtaisten ohjeiden lisäksi puhutaan myös sektorikohtaisista ohjeista, joita kansainväliset toimialayhdistykset laativat. Työ on arvokasta, mutta harmonisoinnin puutteesta johtuen tässäkin piilee riskinsä: eri tuoteryhmien toimijat saattavat pyrkiä minimoimaan omille tuotteilleen kohdistuvat ympäristövaikutukset. Käytännössä siis esimerkiksi yhdistetyissä tuotantomuodoissa kuten elintarvike- ja rehutuotannossa tai liha- ja maidontuotannossa tulisi eri toimijoiden sopia yhdessä, miten yhdistetyn tuotannon ympäristövaikutukset jaetaan, eli allokoidaan tuotteiden kesken. Tästä johtuen laskennan harmonisointi säilynee jatkossakin sektorirajat ylittävänä kansainvälisenä haasteena.

Elintarvikkeiden hiilijalanjälkien laskentamenetelmiä vertailtiin Foodprint Tools -hankkeessa myös julkaistujen tieteellisten artikkeleiden kautta neljässä tuoteryhmässä, maidossa, sianlihassa, leivissä ja riisissä. Elintarvikkeiden hiilijalanjäljet vaihtelivat tuoteryhmien sisällä merkittävästi, mutta tutkimusten epäyhtenäiset toimintaperiaatteet ja tutkimustuloksien heikko jäljitettävyys hankaloittivat tutkimusten yksityiskohtaista vertailua. Tutkimusten tulokset eivät olleet vertailukelpoisia, koska tutkimusten tavoitteet ovat olleet erilaisia ja niissä käytetyt menetelmät eivät olleet yhteneväiset. Raportoinnin epäselvyys ja puutteellisuus ilmeni melko nopeasti useiden tutkimusten kohdalla. Yleisimmät syyt tutkimustulosten välisiin eroihin olivat erilaiset metodologiset valinnat (esim. allokoinnit ja järjestelmärajaukset), eri tuotantotekniikat, eri tuotanto-olosuhteet (ilmasto, maaperä ym.) sekä laskennassa käytetyn tiedon laatu. Selvää käsitystä näiden eri tekijöiden vaikutuksen laajuudesta lopputulokseen ei pystytty muodostamaan hiilijalanjälkitutkimuksien raportoinneissa olleiden puutteiden vuoksi.

\section{Elintarvikeala puimassa hiilijalanjälkiä työpajoissa}

Elintarvikealan yritykset ja eri sidosryhmät ovat olleet laajasti aktiivisesti mukana ideoimassa ja työstämässä elintarvikkeiden hiilimerkintöjen laskentaohjetta ja arvioimassa erilaisia ympäristö- ja hiilimerkintöjä. Työpajoissa on ollut mukana elintarvikealan edustajia alkutuotannosta, teollisuudesta, 
kaupasta, kansalais- ja kuluttajajärjestöistä, hallinnosta ja tutkimuslaitoksista sekä muista asiantuntijaorganisaatioista.

Ensimmäisessä työpajassa pohdittiin erilaisten hiili- ja ympäristömerkintöjen vahvuuksia ja heikkouksia. Suosituimmiksi merkeiksi nousivat monikriteerinen ympäristömerkki ja yksityiskohtaista hiilijalanjälkitietoa vaativat hiilimerkinnät, erityisesti ns. väriskaalaan tai liikennevaloon perustuvat hiilijalanjälkimerkinnät.

Toisessa työpajassa pureuduttiin kehittämisen ja merkintöjen pohjaksi tarvittavan tuotteiden koko tuotantoketjusta kerättävän tiedon tuottamisen haasteisiin. Keskusteluun nousivat esimerkiksi tiedon tarve ja selkeys, epävarmuus ja epäselvyys tietojen luovuttamisesta, kustannukset ja työmäärä. Samalla kuitenkin löydettiin myös ratkaisuja, hyviä tavoiteltavia periaatteita ja motivaatiotekijöitä, kuten tiedon lisääminen, oikeudenmukaisuus koko ketjussa, benchmarking sekä ketjun toimijoiden avoin keskustelu, viestintä ja ketjun toimijoiden yhteisten tavoitteiden asettaminen.

Kolmannessa työpajassa keskusteltiin alustavasta luonnoksesta elintarvikkeiden ympäristövaikutusten laskentasuositusohjeesta, josta seuraavan kerran tullaan keskustelemaan isossa avoimessa työpajassa 2012 alkupuolella. Keskustelua ja parantamista ovat toistaiseksi herättäneet esimerkiksi kysymykset yksityiskohtaisista rajauksista, kuluttajavaiheen sisällyttämisestä, laskentakaavoista ja -parametreistä sekä tiedon laatuvaatimuksista ja ajallisesta kattavuudesta. Seuraavassa työpajassa keskitytään allokointiin.

\section{Kohti laajempaa ympäristövastuuta - muut jalanjäljet tulevaisuudessa samalle tasolle}

Hiilijalanjäljen ohella elintarviketuotantoon liittyy monia muita ympäristövaikutuksia ja -ongelmia, kuten rehevöityminen, monimuotoisuus, ekotoksisuus, alailmakehän otsonin muodostuminen, maan käytön ja laadun muutokset, maaperän pilaantuminen, luonnonvarojen ehtyminen, jätteet ja hiukkaspäästöt. Koska elintarvikeketjujen elinkaariset ympäristövaikutukset ovat hyvin moninaiset, tarvitaan tietoa kaikista ympäristökuormituksista ja niiden merkityksestä ympäristölle, kuluttajavalinnoille ja liiketoiminnalle. Näitä eri ympäristötekijöitä ja näkökulmia ei ole systemaattisesti yhdistetty yhteen ja samaan arviointikehikkoon puhumattakaan siitä, että niitä olisi systemaattisesti käyty läpi samanaikaisesti niin lainsäädännön, ympäristöongelmien laajuuden ja niihin puuttumisen, potentiaalisten riskien kuin sidosryhmien näkökulmasta, ja pohdittu mitä se tarkoittaisi yritysten ympäristövastuun kannalta.

Kaiken kaikkiaan Suomen näkökulmasta ympäristövastuun tarkempi määrittäminen ja elinkaarilaskennan kansallinen kehittäminen kattamaan kattavasti myös muut jalanjäljet, kuten vesi- ja ravinnejalanjäljet sekä aktiivisuus kansainvälisellä tasolla on tärkeää, jotta laskenta- ja kehitystyöhön voidaan vaikuttaa Suomen ja suomalaisen tuotannon näkökulmasta. Alan kansallisen tahtotilan tunnistamista ja etenemissuunnitelman laatimista elintarvikkeiden ilmasto- ja muiden ympäristövaikutusten laskennasta ja viestinnästä tulee jatkaa. Näyttäisi siltä, että tulevaisuudessa ilmastovaikutustarkastelun rinnalle tärkeiksi ja niin ikään elintarvikekenttää muokkaaviksi seikoiksi ovat jäämässä ainakin kysymykset Itämeren tilasta, puhtaan veden kulutuksesta (vesijalanjälki) ja resurssien niukentumisesta.

\section{Lisätietoa: Foodprint-hankkeen kotisivut www.mtt.fi/foodprint}

\section{Kirjallisuus:}

DHCF (2009) Carbon Footprinting of Horticultural Products for business to business communication, Calculating greenhouse gas emissions of horticultural products as a specification of the PAS2050 protocol.

IDF, Bulletin of the International Dairy Federation 445/2010 A common carbon footprint approach for dairy, The IDF guide tostandard lifecycle assessment methodology for the dairy sector

ILCD-käsikirja (2010) International Reference Life Cycle Data System, General guide for Life Cycle Assessment - Detailed guidance, JRC, European Commission, European Union 2010

ISO (2006) Environmental managing. Life Cycle Assessment. Principles and framework. ISO 14040.

ISO (2006) Environmental managing. Life Cycle Assessment. Requirements and guidelines. ISO 14044. 
ISO (2011) Carbon footprint of products - Requirements and guidelines for quantification and communication. ISO 14067-2:2011 (luonnos)

Katajajuuri, J.-M., Pulkkinen, H., Saarinen, M., Silvenius, F. \& Nurmi, P. 2010. Development and harmonisation of a Finnish methodology for the calculation of carbon and other footprints for food products. In: Bruno Notarnicola et al. (editors). LCA food 2010: VII international conference on life cycle assessment in the agri-food sector: Bari, Italy Sebtember 22-24, 2010. LCA food 2010 : VII international conference on life cycle assessment in the agri-food sector p. 77-81.

Life Cycle Assessment Methodology for Australian Rural Industries RIRDC, Publication No. 09/028, Project No. PRJ-002940.

PAS2050 (2008) Specification for the assessment of the life cycle greenhouse gas emissions of goods and services, Publicly available specification, BSI.

WRI/WBCSD (2009) The Greenhouse Gas Protocol Initiative, The Foundation for Sound and Sustainable Climate Strategies, Product Accounting \& Reporting Standard.

Pulkkinen, H., Hartikainen, H.\& Katajajuuri, J.-M. 2011. Elintarvikkeiden hiilijalanjälkien laskenta ja viestintä. Climate Communication I -hankkeen loppuraportti. MTT raportti 12. $40 \mathrm{~s}$.

Pulkkinen, H., Katajajuuri, J.-M., Nousiainen, J. \& Silvenius, F. 2010. Challenges in the comparability of carbon footprint studies of food products. In: Bruno Notarnicola et al. (editors) LCA food 2010: VII international conference on life cycle assessment in the agri-food sector: Bari, Italy, September 22-24, 2010. LCA food 2010: VII international conference on life cycle assessment in the agri-food sector p. 65-70.

Pulkkinen, H., Krogerus, K., Katajajuuri, J.-M., Saarinen, M., Hartikainen, H., Silvenius, F. \& Yrjänäinen, H. 2011. Developing LCA methodology guide for the food industry. In: LCM 2011 Towards Life Cycle Sustainability Management. 28-31 August, Berlin. Conference Proceedings. 